\title{
Agreement and Consensus Between Government and Rebellion Groups During War Politics in Ampara District of Sri Lanka
}

\author{
Athula Withanawasam \\ Department of Political Science, Faculty of Arts, \\ University of Peradeniya, \\ Peradeniya 20400, Sri Lanka. \\ E-mail: withanawasam@gmail.com
}

Received: February 20, 2021

Accepted: March 25, 2021 Published: March 30, 2021

doi:10.5296/ijssr.v9i1.18470

URL: https://doi.org/10.5296/ijssr.v9i1.18470

\begin{abstract}
This article is about the agreement and consensus between government and rebellion groups during war politics with special reference to Ampara district in Sri Lanka. The article argues that war causes transforming normal pattern of politics if we perceive of war as power struggle. The article further argues that to understand politics and power struggle during war requires conceptualization of war politics. Therefore, this article has attempted to conceptualize war politics and applied it to understand the nature and content of war politics in Sri Lanka in general and in Ampara district in particular during the period of protracted civil war. The data for the study were collected from both primary and secondary sources. Primary data were extracted from the extensive field works while secondary data were collected from desk analysis. The above data were descriptively analyzed and presented in this paper as summaries of arguments and author's interpretation. This study has found that war causes dual power making civilians and officers becoming clueless on whose orders were to be obeyed because war resulted in crisis of the state. The study has also found that war politics results in syndromes of incapacitated, establishment of dual power and existence of reciprocal understanding between government and rebellion groups during war. The study concludes that there is a probability of an emerging agreement and consensus between actors of governmental politics and war politics during wars to achieve their strategic objectives.
\end{abstract}

Keywords: war politics, civil war, dual power, normal politics, militarized politics, war economy, Ampara district, Sri Lankan state, LTTE 


\section{Introduction}

Politics has been interpreted as a peaceful resolution of conflict or the way out of inherent chaos and conflict that emerge out of insatiable desires and limited resources (Hobbes, 1651[1968]). However, if politics is interpreted as a power struggle, war causes changes in the game of politics. There is voluminous and substantial amount of literature on politics in general. Yet, the scholarship on politics has paid scant attention on what happened to normal politics during civil wars. There are passing remarks on war politics either in conflict resolution or political studies that could be used to conceptualize politics of war in a more scientific way. The overall objective of the present study is to conceptualize what is meant by war politics and apply the conceptual construct to understand the nature and content of politics of the protracted war period from 1983 to 2009 in Sri Lanka.

\section{Methodology of the Study}

This study is qualitative in nature and has used both primary and secondary data for the analysis of major themes and issues related to the study. The primary data were collected by through multiple data gathering techniques such as interviews, focus group discussions, participatory observations and field notes. The secondary data were collected from books, books chapters, journal articles and reports of the government and civil society organizations. Those collected data have been descriptively analyzed and presented in this paper as direct quotations, summaries and interpretations. This paper has not incorporated the extensive version of primary data findings such as interviews due to some ethical reasons, however, the opinions and perspectives towards war politics collected from the primary sources are summaries in this paper under the thematic findings. Ampara district was selected as the study site to test the nature of war politics in Sri Lanka for different reasons. The primary reason is to test the nature of war politics under the multi-cultural context since the district has been maintaining a multi-cultural character from its inception. Accordingly, the Ampara district is marked by the presence of Sinhalese, Tamils and Muslim in an equal and competing manner to a certain extent. Secondly, the Ampara district has been regarded by almost all the parties to the conflict as strategically important area in civil war and war politics. The following section summarizes major findings of this study under different thematic topics.

\section{Major Findings}

\subsection{War Politics}

As there are little studies on war politics, interpreting war politics has become a daunting task for any student of politics. However, surveying of literature on civil war is helpful in identifying certain features and characteristics inherent in war politics. The literature on civil war has shed light on associated features of war politics which include state crisis, emergence of dual authority system instead of singular authority, militarized politics, repeated internal displacements, culture of violence, coexistence of electoral politics and war politics, war economy etc.

The concept of war politics remains poorly conceptualized in the literature of political 
science and conflict resolution. For the purpose of present study, 'war politics' is defined as the emergence of a specific form of politics in time of protracted civil war. For the purpose of clarity, politics can be grouped into two as normal politics and war politics. The distinguishing feature of war politics from that of normal politics is the transformation of political process leading to break down of governmental politics in part or full. The specificity of war politics is that it prevents normal governmental politics and forces it to change routine operational styles. Protracted civil war challenges the power of the state. Consequently, there emerges a dual power system which challenges the sovereignty of the state together with its agent called government. The democratic practices and institution associated with normal politics such as rule of law, legitimacy of the government, accountability of decision making and implementing bodies, competitive political party system and pressure group activities, periodical free and fair elections and functioning of healthy civil society organizations are put into jeopardy and risk during wars (Imai \& Weinstein, 2000). This situation of breaking down of normal politics requires reinterpretation of governmental politics in the context of war.

\subsection{Breaking Down of Normal Politics}

William Zartman has recognized that normal politics is associated with government and war politics leads to breaking down of normal politics or governmental politics (1995a). He has elaborated that breaking down of normal politics takes off with the emergence of internal conflicts. Normal politics or governmental politics goes hand-in-hand with the activities of party politics. According to this interpretation, normal politics takes place in the institutions of President or Cabinet of ministers, Legislatures and Departments of the Government which discharge functions of the government. Governmental politics is carried out by specific groups like politicians and civil servants. Accordingly, rank-and-file of the society which do not have direct role in running the government are regarded irrelevant in the governing process of the country. This type of understanding equals to the common-sense notion of politics. Being the government, the agent of a state's interests, governmental politics influences on the society in many ways. Early social contract theorists have held the view that where there is any government capable of allocating official value, such situation leads to breaking of social solidarity. It would result in emerging to a war like situation where each fight against other (Hobbes, 1651[1968]). This conceptualization defines government politics as a system of peaceful resolution of conflict where superior power of the state decides the course of conflicts without leading to violence. It implies negotiation and compromise rather than resorting to crude and coercive power to maintain law and order in the society. Thus, normal politics denotes a process of resolving disputes through the facilitation of third party which opens opportunities for dialogue, negotiation and compromise without making use of military settlement against one another. Normal politics always provides an alternative to weapons and armories. Duverger (1972), the French political scientist has highlighted politics as attempts at avoiding bodily violence. Democracy is intermediate settlement and agreement according to him.

There are other functions performed by the government in a society. It provides protection for the members of the state and maintains law and order. Thomas Hobbes (1651) believed there 
shall be a strong government to provide security for members of the state. He also identified protecting the political society from invasions by external powers as the key functions of the state. Military forces were meant to discharge this responsibility. Keeping law and order which is a function internal to the political society has been recognized as a responsibility of the police in many societies, yet, military also has been summoned from time to time as situation required in modern society. German sociologist Max Webber (1948) pointed out that the state alone possesses the right to the monopoly of coercive power. The other important role of government politics is the protection of property and other rights. Locke has stated the significance of government in protecting the economic right to own private property. There are certain rights that can be provided only by the government. Right to expression, right of association, right not to be discriminated and prevention from torture are some of such rights.

The politics of government is also instrumental in enhancing economic prosperity of a country and distributing benefits of such economic gains in reasonable and justifiable manners. Many has argued the necessity of government to assure social justice. The rationale behind such argument is that none-state organizations and actors' voluntary intervention to help poor and needy people of the society is not always the case unless there is authoritative government which could be able to redistribute the economic gain as a whole. Further, provision of a safety net for needy people has also become the responsibility of the government. The needy people are the powerless minors, the aged people and the disables (Mahajan, 2013). In the course of evolution of society government has embraced other roles such as provision of education and health, infrastructure development and maintenance, pension, periodical elections, development etc. The history of civil wars throughout the globe has revealed that war resulted in ceasing or disruption of functions performed by government in normal political context together with agencies that discharge those responsibilities.

History has also revealed that type of collapses may either be partial or total. Breaking down or collapses of normal politics refers to such situations described above. Consequently, one who studies war politics requires a reinterpretation of government politics with a specific reference to war. Such endeavor needs to forecast on how government politics is broken down and new forms of society and politics after such breaking down. State remains supreme in normal times of politics. However, that supremacy is challenged by armed insurgent groups during civil wars. The insurgents challenge the monopoly of physical force by the state. Politics of war situation is characterized by lack of legitimacy for the state and terrified institutions that act on behalf of the sovereign state. The state also tends to get institutions more and more militarized. Thus, state becomes suppressive institution of unprecedented scale. The institutions and practices that occupied an important place in a democratic politics, such as political parties, elections, independent judiciary, civil society organizations, the free media etc. undergo and subjugate to the power and influences of insurgent groups. The cumulative effect of all of the above discusses the negation of the rule of law and violation of human rights both by the insurgents and the state. War politics leads to resolve conflicts through military means instead of peaceful resolution of conflict in normal political process. When civil war is protracted and long-lasting war becomes normal (Uyangoda, 2008). Normalizing of war deprives off the capacity of the state to act as usual. The State runs into a 
crisis in galloping speed. Maintaining law and order, administering civil functions, building and maintenance of infrastructure facilities including roads, provisions of welfare and development activities become daunting tasks for the state in civil war situation.

\subsection{Crisis of the State}

The State might fall into a crisis with political violence or without violence. The State falling into crisis is unavoidable in times of organized political violence (Osinsky, 2008). A civil war takes away the state's capacity to use coercive power within the territory of the state. Consequently, physical foundation together with governing system of the state is being challenged depriving the state's stake in the delivery of public good and service. Public good and service include protection of citizens, maintaining law and order, protection of private property, right to political participation, building and maintaining infrastructure and provision, public health etc. (Rotberg, 2003).

States are classified as weak states, failed states and broken states according to the capacity of the state to deliver public good. A civil war may lead a state to any form of condition discuss and above (Rotberg, 2003). A most common form of state crisis is the failed state. The pioneer scholar on fail states Rotberg (2003) has interpreted the failed state as the one which has become unable to deliver public good within the state or is disinterested in delivering public goods. Zartman (1995b) characterized a failed state as that which is unable to perform the function of the state. Frequent occurrence of civil wars in a failed state has to do with antagonism associated with race, ethnicity, religion etc. Demand for power sharing or for autonomy seems to justify the violence of rebellion groups. As state becomes unable to provide protection to some territories of the state, it loses authority in some parts of such a failed state. Legitimate authority of the state becomes confined to the areas of capital city and particular ethnic areas. According to Rotberg (2003), the scale of failure of the failed states can be measured in relation to the scale of geographical areas controlled by the state during the nights.

Some scholars have drawn much attention to the strength of the organs of government in characterizing failed states. In failed states, the executive becomes stronger and stronger in relation to the legislature and the judiciary. The Legislature becomes incompetent and the judiciary subordinated to the executive. The bureaucracy loses its professionalism and becomes a mere appendage carrying out the orders of the executive. The only institution that maintains the degree of integrity is the military, yet, highly politicized (Rotberg, 2003). Concentration of economic opportunities in the hands of a few is another characteristic feature of a failed state. It results in either the ruler or close allies of the ruler or oligarchy becoming the rich while overall majority of the people becoming poor. Key responsibility of the state i.e., assurance of wellbeing to each and every citizen cannot be found in failed states (Rotberg, 2003).

The biggest political challenge ahead of political leadership of a failed state is the strengthening of the state so as to unite the society. The Government of a failed State does not last long for the provision of protection and the physical existence depends on the strategies chosen by the rulers of such a society. In this context, scarce resources are being used for 
militarization purposes.

Rotberg (2003) pointed out that the State failing is a process. A weak State may be converted into a failed state while a failed state becoming a weak state. Some of the weak states may become broken states. A classic example is the Somalian state. It remains a failed state in 1991 at the initial stage of civil war. Consequently, it became a broken state in the context of civil calamities. Indonesia remained a failed state for it has been able to control a major part of its territories projecting its authority while ensuring public good (Rotberg, 2003).

\subsection{Dual Power}

Dual power has been used as a synonym for the words double power, dual authority and dual sovereignty. The concept of dual power has gained wider currency in modern war literature. According to Tilly (1978), a war situation would lead to the breakup of the monopoly of the coercive power of the state and consequently a rebellion group tends to claim stakes on state power. As rebellion groups strive to divide the sovereignty of state, a civil war becomes unavoidable. It can be pointed out that the reason behind dual power has to do with state losing monopoly of coercive power and resulting in deep transformation of political institutions of a country.

Many scholars have observed that dual power situation would result in non-acceptance of state authority or collapse of state power in areas where it is challenged (Zartman, 1995b; Milliken, 2003). However, it has to be noted that breakup of state power does not imply losing of controlling of those areas. What really happens is that the co-opting of governing structures by the structures developed by the rebellion. Labeling those areas as ungoverned is erroneous. In reality those areas become areas under rebellion control (Mampilly, 2011). Rebellion groups claim sovereignty over those areas (Weintein, 2007; Arjona, 2009; Mampilly, 2011). Accordingly, there is no un-governed area under a dual power situation. Instead there are areas governed by the government and areas governed by the rebellion groups. Mampilly (2011) has observed the existence of three types of zones in times of civil war namely, 1) areas controlled by rebellion groups, 2) areas that were competitively controlled by both sides and, 3) areas controlled by government. However, this categorization does not imply that there are areas totally controlled either by government or rebellion groups. The control held by government or rebellion groups varies according to winning and losing in the battle ground.

Many have forgotten one important dimension of state power with regard to areas under the control of rebellion groups. That is, the state's ability to intervene into and disrupt political activities and administrative mechanism of rebellion groups with difficulties. The State has got the power to use coercive physical force within its territories without being blamed. That is the international norm that governs the state system. On the other hand, rebellion groups also behave in the same manner with regard to inhabitants of areas under their control while they strive to win hearts and minds of the people in areas where neither side is capable of total control.

Rebellions attempt at developing a governing structure clearly demonstrates duality of power 
operative in their areas. This distinguishes between the established notion of rebellion and the real nature of the rebellion during a civil war time. Rebellions are not mere combatants. They are also rulers attempting to control and rule the people of their areas. The rebellions in Angola, Colombia, Indonesia, Israel, Nepal and Russia are cases in point. They have developed a subtle mechanism to rule and control people in their respective areas of control. Mampilly (2011) has observed the rebellion organizations cannot be considered as terrorist out fits for they have acquired political significance in their attempt to provide services with the objective of obtaining public support for their activities. Political violence and threats alone cannot sustain their control. They are compelled to device a mechanism which can obtain loyalty and obedience of the people. In this context, provision of public good and services have to be understood as instruments that generate public support and legitimacy for their rule.

\subsection{Militarized Politics}

One of the fundamental features of politics in a civil war situation is that of politics becoming militarized. There are certain reasons for militarized politics in a war context. First and foremost, has to do with the historical condition. Since the 19th century the state with a democratic governing structure has established the military under a professional leadership separately from the rest of civilian or bureaucratic structures. Provision of national security was the sole task assigned to the military. However, with the emergence of new challenges such as internal calamities and terrorism, states were compelled to strengthen military forces to face the new challenges. Since the 20th century, militaries were given functions that go beyond their traditional task. Ultimate result has been the paving way for military intervening into the civilian affairs (Stepan, 1998). The second, the political structure of the modern state itself has provided avenues for the military to intervene into the civilian affairs. According to Stepan (1998), this is a privileged position given to the military. He went on explaining the privileged position of the military by pointing to the facts such as constitutional recognition of independence of the military: the relationship maintained by the military with the head of the state, its role in collecting secret information for the state and its nexus with the legal structure of the state. Stephan has further brought out the possibilities of leading of the civil administration to chaos due to military interferences. When militaries are over privileged, democracy becomes impossible. Thirdly, the changes of the type of wars and fighting have opened space for the military to intervene into civilian affairs. In the first world war context, new wars are taking place in and among the people. Combatants fight behind the people and make use of people as shields (Smith, 2006).

The militarization of politics in Sri Lanka can be explained with the insights that have been discussed above. Sri Lanka inherited a ceremonial army when it gained political independence at least for the first two decades of the independence. When the state was challenged by the insurgent groups in 1970s, Sri Lankan military forces were strengthened and invited to take care of the civilian affairs for the first time. The presence of the military in civilian affairs of the state increased in galloping speed when the Sri Lankan state was challenged by separatist Tamil militant groups. Ideology of privileging the military in certain spheres firmly took roots during the civil war for its role in protecting the state and the 
territorial integrity of the state.

Military forces have started to take stakes in other spheres of activities while performing its traditional functions of protecting the state and territorial integrity of the country. This new role has been much wider and broader which comprises a task of military and civilian nature. Performing of none military tasks during the civil war period has resulted in directly connecting military with civilian affairs. This direct involvement of military in civilian affairs made it possible for the military to govern civilians. It has resulted in military involvement in formulating and implementing the policies that affect the lives of the civilians. It was given special attention and priority to the needs, suggestions of the military in designing buildings, bridges within north and east in Sri Lanka during the war. Further, military personnel were appointed to head the district administration of the respective provinces. They were decided how to make accesses for the essential goods and services for the civilians. They were engaged even in teaching in Sinhala medium schools that blurred the distinction between civil and military affairs.

The civil war situation required a kind of coordination between civil and military arms of the government to provide public goods and services which were an inalienable duty of the state. This coordination led to civil and ordinary people's lives under the control of military personnel for protecting civil life and suppressing separatist groups which the responsibility of the military. This led to subordination of civil officers as well as politicians. Further, military also kept vigorous vigilance over civil life. It was military that supervised traffic, transportation of goods and services, issuing of license to move from one place to others overlooking and decision making in relation to cultivation and fishing and maintaining vigilance over none governmental organization activities. All of the above substantiate the fact that military was not confined to its traditional role of protecting the state and territorial integrity. Thus, it can be concluded that military has become a key stakeholder of the state.

\subsection{Repeated Internal Displacement of the Civilian}

A careful observation of the disastrous situation reveals that civil war causes repeated internal displacement of civilians (Hegre \& Holtermann, 2012). As internally displaced persons they are in a disadvantageous position rather than the refugees, for they are still citizens of the country where they have been displaced. Hence, they are under the eager of the authority of the government of their country. They cannot demand more rights than the rest of the citizens of the country (Hathaway, 1991; Vincent, 2000). Internally displaced persons are then categorized as different groups. They have to undergo different dilemmas for sometimes they belong to different cultural groups. Sometimes it damages the very dignity of human beings. In the case of Sri Lanka there were plenty of such kind of complex social conflicts in places where internally displaced persons were camped. This internal displacement has once again led to increasing social divisions among displaced persons. Sometimes well to do layers of internally displaced persons never return to the original habitat leading to the degeneration of social bonds. Further, war also has led to changes in the gender roles. Internal displacement necessitated plenty of hands to feed the family, thus compelling female partner of the family to engaging in income earning activities. 


\subsection{War Economy}

War economy was a concept used to explain dynamic of economies during the first and second world wars (Karbo \& Nelson, 2010). The concept had regained currency in 1990s as a result of focus on explaining the economic dimension of conflict academic and policy perspective (Ballentine \& Sherman, 2003). According to tradition war has been perceived as forced that leads to economic breakdown. However, war has been recognized as a means to gain profit, power and alternative form of providing protection (Ballentine \& Sherman, 2003). At present, the concept of war economy is used to indicate dynamics of whole of economy which is connected with politics and war. Some of scholars have made use of the above notions to bring out patterns of economic relations in times of violent conflict (Ballentine \& Sherman, 2003).

Naidoo (2000) has employed the term war economy to explain mutual acquisition and exploitation of resources so as to prolong a conflict. Some have made use of the concept in a narrower sense to include almost all the economic activities (Pugh et al., 2004). Fekete (2004) had pointed out that war economy does not end with the end of a violent conflict. According to him, in a war economic situation war cannot prevent earning money through the war (Berdal, 2003). Another dimension of war economy is the militarization of the economy itself (Ballentine \& Sherman, 2003).

Goodhand (2001) groups war economy into three categories i.e., combatant economy, shadow economy and survival economy. He observed that each of the above war economies provide opportunities for main actors of the war to face the rival successfully, to maintain the war and to gain economic benefits. Each of the above economies is interrelated and has got differences also. Further, these economies are characterized by actors who have got their own interests. The key actors are forces of the government, rebellion groups, foreign and local spoilers of conflicts and war entrepreneurs. Production related to combatant economy, mobilization and resource allocation help to generate resources to perpetuate the war. Goodhand (2001) observed that illegal economic activities, extortion, strategically use of resources, foreign aids, money remitted by diaspora, prelate activities feed the war economy.

The shadow war economy is composed of economic activities that generate profit for traders, drug smugglers etc. Illicit trade or secret economy under a shadow economy generates a network that produces reciprocal benefits. The beneficiaries of this economy are sometimes not directly involved in war. Survival economy provides space for the people a means of living amidst war. The main actors of this economy are poor households and communities. Those people become capable of living by engaging in subsistent economic activities such as agriculture, petty trade, illicit importation of goods and through remittances by diaspora (Goodhand, 2001).

Political elites and rebellion movements become the protectors of the war economies. Political elites make use of military forces for personal aggrandizement through trade and other ventures. Meanwhile a rebellion movement makes use of strategical locations to gain commercial benefits. War economy also provides benefits to external actors. However, war economy as a whole produces disastrous effects on society. It causes poverty of the state 
(Ballentine \& Sherman, 2003). Thus, war economy can be regarded as the extreme opposite of the peace economy. The two economies operate in two different situations. Peace economy produces economic growth while war economy prevents economic growth. War economy cannot induce foreign investments. The economic growth that is produced by peace economy can be used to capitalize further economic growth and development projects. The economic growth that accompany war economy has to be used to allocate money for the war and to feed elites (Broodryk \& Solomon, 2010). The precondition to find a way out of war economy is the establishment of peace and democratic governance (Karbo \& Nelson, 2010).

The war politics which comprised all of the above characteristics become the determining factor of the all the civilian and military affairs of the country during a civil war. However, this does not imply a withering away of normal politics in a war-torn society. What happens is the breakdown of governmental politics or the inability of normalizing the polity as witnessed prior to the war in most of the cases. The position of the governmental politics depends on the capacity of the government to face the challenges posed upon it by war politics.

\section{Discussion}

In classifying Sri Lanka into the category of a failed state, one has to draw attention to the nature of the crisis that Sri Lanka had encountered. A student of politics may notice several facets of the crisis that Sri Lanka has come across. Uyangoda and Bastian (2008) point out the government of Sri Lanka has lost her capacity to exercise exclusive legitimate use of coercive power to protect citizens and assure economic prosperity. In the case of Ampara District, the area controlled by Government of Sri Lanka and LTTE varied from time to time. However, neither side was able to totally control the area of the district. Consequently, as Warnapala (1994) had observed government of Sri Lanka had been incapable and its legitimacy was questioned. According to some of the scholars who have studied the nature and the content of Sri Lankan state crisis, have shared many things in common with that of a failed state (Jackson, 1990; Krasner, 2004; Zartman, 1995b). During the civil war, the LTTE had controlled around 15 percent of its geographical areas with varying degrees from time to time. Sri Lanka had been unable to submerge LTTE insurgency for about three decades. However, Rotberg did not categorize Sri Lanka as a failed state for its government was able to control areas of majority Sinhalese numbering to 80 percent and to maintain roads, school and hospitals within limited areas of Northern and Eastern provinces of the country. However, he has entirely forgotten the governing structure run by the state. Mampilly (2011) pointed out that one of the key features of state crisis is that a non-state actor controlling a part of the country through their own governing structures. As some parts of the Northern and Eastern provinces of the country had been under the control of LTTE, it can be argued that Sri Lanka remained a failed state of a kind that was discussed earlier.

It is observed that duality of power arises when a state loses its supremacy of power in certain parts of the state and non-state actors disregard the state power in certain parts of the country (Justino, 2012). It has already observed that Sri Lanka had lost its sovereignty in areas that were under the control of LTTE during the war (Uyangoda, 2008). The ground reality was 
that Government of Sri Lanka considered the district as strategically important as it was the gateway to the rest of the country. The LTTE also regarded the district was very important for them, since the area could be used to militarily penetrate the country and terrorize the government and the country.

In this context, it warrants to briefly deliberate on how duality of power took place in the area during war. It is well known that LTTE has controlled many parts of Northern and Eastern part of the country for about three decades. Those areas were known as un-cleared areas. In the case of Ampara, it was not under the control of the LTTE. However, alert and vigilance of the government forces was very high. The rest were termed as cleared areas. The cleared areas were under the control of the government. The former could insert pressure and influence on and over un-cleared areas while the latter was able to do the same in areas which were termed cleared areas. As they have developed an administrative structure to provide goods and services through them, that structure portrayed itself as the civilian bureaucracy of the rebellion government. Even though this administrative arm seems as separated from the military organ of the organization, it was not the case in reality for both were manned by the cadres of the same organization. The LTTE maintained its own police force, a system of judiciary and a banking system. Yet this structure was less significant in the case of Ampara District. This does not imply that the structure was not in operation in the district. There were instances where even Sinhalese sought justice through the police and courts of the LTTE. Taken as a whole the operation of the LTTE, it had demonstrated an aspect of an embryonic state. This situation came close to the conclusion made by Mampilly (2011) that rebellions demonstrated its power through symbols such as flags, traffic police, televising and broadcasting. The same was observed by Stokke that as a shadow state, it had paid special attention to internal and external protection, social welfare and economic development in its state crafting project (2006). It is also observed that LTTE paid its attention to develop formal democratic representative system together with a centralized authoritarian institution of a state. According to this argument the civil war had led to an emergence of a dual state structure together with a territorial division (Stokke, 2006).

There have been twin attempts by LTTE to demarcate the territory for its dream state and to win the hearts and minds of the Tamils through the provision of public goods. However, as Uyangoda has observed provision of education and health services were carried out by the government of Sri Lanka even in the un-cleared territory (Uyangoada, 2008). The lives of the people of uncleaned areas depended on a hybrid system of administration of the LTTE organization and the government of Sri Lanka.

The Sri Lankan government provided public goods to the people of un-cleared areas despite the war between government and the LTTE. This amounted to the denial of the claim made by LTTE for sovereignty within their areas of control.

LTTE had had no alternative to the provision made by government of Sri Lanka in the field of public goods and services. It was compelled to corporate with the government of Sri Lanka in the field of civilian welfare. This resulted in a kind of corporation between the government of Sri Lanka and the LTTE with regard to the provision of public goods while the military 
confrontation took place against each other. The results of that hidden or unexpressed agreement were the accessibility to the public goods and services of the government by the people in the un-cleared areas.

The police force and the judiciary established by the LTTE remained under the control of the organization while the provision of public goods and services of the government was carried out by the bureaucracy of the government. The administrative mechanism headed by a District Secretary like in any other district of Sri Lanka was operative in the district in un-cleared areas provided that the officers of the government bureaucracy were acceptable to the LTTE according to a hidden agreement. There was an understanding that the civil servants must be loyal to both sides simultaneously.

The study helped to identify a few syndromes associated with dual power in a civil war context. They are as follows:

1) The Government becomes incapacitated to maintain its total control in areas under the control of the rebellion.

2) Consequently, this incapacity paves the ways for rebellion groups to established to system of control giving birth to dual power to dual power situation.

3) As a result of the above, both sides to the war become incapable of provisioning public goods and services by individual side alone.

4) Finally, the incapability of both sides leads to a kind of reciprocal understanding and agreement in the sphere of public goods and services.

\section{Conclusion}

The history of war politics in many parts of the world shows different patterns of outcomes of war politics. Where the impacts of war politics are serious and disastrous the governmental politics become a standstill leading to breakdown of the state. Afghanistan and Somalia are cases in point. The other pattern is the partial breakdown of governmental politics. Sri Lanka has witnessed this pattern of outcome. In the case of Sri Lanka, it did not witness a total collapse of governmental politics. Instead, Sri Lanka underwent partial failure of state as well as partial collapse of government. This partial collapse was visible in the Ampara district of the country. However, Sri Lanka was able to go ahead with the democratic electoral process while waging war with the rebel group. The war barred free and competitive electoral politics, competitive party system and the free operation of the civil society organizations in the district and the eastern part of the country. It had made a negative impact over them. However, the war did not result in a total collapse of the civilian administration of the government. One of the important questions that could be raised is 'why' and 'how' war politics and governmental politics went hand-in-hand in the sphere of civil administrative affairs despite differences in terms of objectives, procedures and organizational structure between the two types of politics. It can be observed that there was a mutual understanding between the LTTE, the main actor in war politics and the government of Sri Lanka. This mutual agreement has to do with incongruent strategic objectives of the two parties to the war. Civil administration 
was necessary for both parties to maintain the war. It has already been pointed out in this article, that civil administration was considered by the government of Sri Lanka to save its face in the international community and to maintain its legitimacy as a State. The irony was that even the LTTE thought that civil administration of the government was necessary to achieve its military objectives. Further it thought that civilian officers can be subjugated according to their will and public goods and that services provided through the civilian arms of administration can be used to meet the bare necessities of the people under their control. It was also of the view that cooperating with the civilian administration officers of the area under their control was not problematic because the government intervention in their operation was less. The main conclusion of this study is that there is a probability of an emerging agreement and consensus between actors of governmental politics and war politics during wars to achieve their strategic objectives.

\section{Acknowledgement}

This study was conducted using author's self-fund. The author expresses the gratitude to those who assisted in preparing the manuscript. Author also declare no conflict of interest in the content of the paper.

\section{References}

Arjona, A. M. (2009). Variants of social order in civil war. Unpublished PhD Dissertation, New Department of Political Science, Yale University, Haven, United States of America.

Ballentine, K., \& Sherman, J. (Eds.) (2003). The political economy of armed conflict: Beyond greed and grievance. London: Lynne Rienner.

Berdal, M. (2003). How "New" are "New Wars"? Global economic change and the study of civil war. Global Governance, 9(4), 477-502. https://doi.org/10.1163/19426720-00904007

Broodryk, A., \& Solomon, H. (2010). From war economies to peace economies in Africa. Scientia Militaria: South African Journal of Military Studies, 38(1), 1-24. https://doi.org/10.5787/38-1-77

Duverger, M. (1972). The study of politics (Trans.). Wagoner, R. Surrey: Thomas Nelson and Sons Ltd.

Fekete, K. (2004). Experts consider how to transform war economies. Retrieved from http://www.swissinfo.org/sen/swissinfo.html

Goodhand, J. (2001). Violent conflict, poverty and chronic poverty. CPRC Working Paper 6, Chronic Poverty Research Centre. https://doi.org/10.2139/ssrn.1754535

Hathaway, J. C., \& Foster, M. (2014). The law of refugee status (2nd ed.). Cambridge: Cambridge University Press. https://doi.org/10.1017/CBO9780511998300

Hegre, H., \& Holtermann, H. (2012). Poverty and conflict. In G. K. Brown \& A. Langer (Eds.), Elgar handbook of civil war and fragile states (pp. 39-58). Cheltenham: Edward Elgar Publishing Limited. https://doi.org/10.4337/9781781006313.00010 
Hobbes, T (1951) [(1968)]. Leviathan. London: Penguin.

Imai, K., \& Weinstein, J. (2000). Measuring the economic impact of civil war. CID Working Paper No. 15, Center for International Development, Harvard University. Retrieved November 20, 2019, from https://imai.fas.harvard.edu/research/files/cid.pdf

Justino, P. (2012). War and poverty. IDS Working Paper 391. London: Institute of Development Studies. https://doi.org/10.1111/j.2040-0209.2012.00391.x

Karbo, T., \& Nelson. C. (2010). War economies: issues and options for transformation. Africa Peace and Conflict Journal, 3(1), 13-24.

Krasner, S. D. (2004). Sharing sovereignty: New institutions for collapsed and failing states. International Security, 29(2), 85-120. https://doi.org/10.1162/0162288042879940

Locke, J. ([1690] 1947). An essay concerning the true original, extent and end of civil government. In E. Barker (Ed.), Social contract (pp. 1-144). Oxford: Oxford University Press.

Mahajan, V. D. (2013). Political theory. New Delhi: S. Chand Publishing.

Mampilly, C. H. (2011). Rebel rulers: Insurgent governance and civilian life during war. London: Cornell University Press.

Milliken, J. (Ed.). (2003). State failure, collapse and reconstruction. Malden: Blackwell.

Naidoo, S. (2000). The role of war economics in understanding contemporary conflicts. Johannesburg: Institute of Global Dialogue.

Osinsky, P. (2008). War, state collapse, redistribution: Russian and German revolution revisited. Political Power and Social Theory, 19, 3-38. https://doi.org/10.1016/S0198-8719(08)19001-9

Pugh, M. C., Cooper, N., \& Goodhand, J. (Eds.). (2004). War economics in a regional context. Boulder: Lynne Rienner Publishers.

Rotberg, R. I. (2003). Failed states, collapsed states and week states: Causes and indicators. In R. I. Rotberg (Ed.), State failure and state weakness in a time of terror (pp. 1-26). Washington D.C.: Brookings Institution Press.

Smith, R. (2006). The utility of force: Theories, actors, cases. Oxford: Oxford University Press.

Stepan, A. C. (1998). Rethinking military politics: Brazil and the Southern Cone. New Jersey: Princeton University Press.

Stokke, K. (2006). Building the Tamil Eelam state: Emerging institutions and forms of governance in LTTE-controlled areas in Sri Lanka. Third World Quarterly, 27(6), 1021-1040. https://doi.org/10.1080/01436590600850434

Tilly, C. (1978). From mobilization to revolution. New York: Random House. 
Uyangoda, J. (2008). Sri Lanka: the state changes face. Economic and Political Weekly, 43(43), 8-9.

Uyangoda, J., \& Bastian, B. (2008). State responsiveness to public security needs: The politics of security decision-making-Sri Lanka country study. CSDG Papers No. 15. London: Conflict, Security and Development Group.

Vincent, M. (2000). IDPs: Frights and Status. Forced Migration Review, 8, 29-30.

Warnapala, W. (1994). Ethnic strife and politics in Sri Lanka: An investigation into demands and responds. New Delhi: Navrang.

Webber, M. (1948). Politics as a vocation. In H. H. Gerth \& C. Wright Mills (Eds. \& Trans). From Max Weber: Essays in sociology (pp. 77-128). Oxon: Routledge.

Weinstein, J. M. (2007). Inside rebellion: The politics of insurgent violence. New York: Cambridge University Press. https://doi.org/10.1017/CBO9780511808654

Zartman, I. W. (Ed.). (1995a). Elusive peace: Negotiating and end to civil wars. Washington, D.C.: The Brookings Institution Press.

Zartman, I. W (Ed.). (1995b). Collapsed states: The disintegration and restoration of legitimate authority. London: Lynne Rienner Publishers.

\section{Copyrights}

Copyright for this article is retained by the author(s), with first publication rights granted to the journal.

This is an open-access article distributed under the terms and conditions of the Creative Commons Attribution license (http://creativecommons.org/licenses/by/4.0/). 